\title{
ARE OUR ORCHIDS SAFE DOWN UNDER? A NATIONAL ASSESSMENT OF THREATENED ORCHIDS IN AUSTRALIA
}

\author{
GARY N. BACKHOUSE \\ Biodiversity and Ecosystem Services Division, Department of Sustainability and Environment \\ 8 Nicholson Street, East Melbourne, Victoria 3002 Australia \\ Gary.Backhouse@dse.vic.gov.au
}

KEY WORDS:threatened orchids Australia conservation status

\section{Introduction}

Australia has about 1700 species of orchids, comprising about 1300 named species in about 190 genera, plus at least 400 undescribed species (Jones 2006, pers. comm.). About 1400 species (82\%) are geophytes, almost all deciduous, seasonal species, while 300 species (18\%) are evergreen epiphytes and/or lithophytes. At least $95 \%$ of this orchid flora is endemic to Australia. While the tropical and subtropical epiphytic/lithophytic orchid flora is low by world standards, the temperate terrestrial orchid flora is amongst the richest and most diverse of any comparable region in the world.

Like many places on our planet, biodiversity and natural habitats in Australia have suffered substantial declines and range in abundance through agricultural, industrial and urban development. The Australian Government Environment Protection and Biodiversity Conservation Act 1999 (EPBC Act) currently lists 106 species of flora and fauna as extinct, and a further 1582 species as threatened, in Australia.
Many orchid species are included in this list. This paper examines the listing process for threatened orchids in Australia, compares regional and national lists of threatened orchids, and provides recommendations for improving the process of listing regionally and nationally threatened orchids.

\section{Methods}

The national government of Australia and each of the six Australian state and two territory governments have processes for listing threatened species under biodiversity conservation legislation within each jurisdiction (Table 1). To establish the number of threatened orchids included in these lists, the schedules of each Act were checked and listed orchids identified (Appendix 1). The State of Victoria also maintains a published 'advisory' (non-legislative) list of rare or threatened flora. This list was also checked for numbers of threatened orchids and compared against the state legislative list. Comprehensive reviews of the conservation status of orchids at the

TABLE 1. National and state/territory legislation listing extinct, rare or threatened orchids in Australia.

\begin{tabular}{l|l} 
Jurisdiction & Legislation \\
\hline Australia & Environment Protection \& Biodiversity Conservation Act 1998 \\
\hline Australian Capital Territory & Nature Conservation Act 1980 \\
\hline New South Wales & Threatened Species Conservation Act 1995 \\
\hline Northern Territory & Parks \& Wildlife Conservation Act 2000 \\
\hline Queensland & Nature Conservation Act 1992 \\
\hline South Australia & National Parks \& Wildlife Act 1972 \\
\hline Tasmania & Threatened Species Protection Act 1995 \\
\hline Victoria & Flora \& Fauna Guarantee Act 1988 \\
\hline Western Australia & Wildlife Conservation Act 1950 \\
\hline
\end{tabular}


state level, for South Australia (Bates 2006), and Victoria (Backhouse \& Cameron 2005, DSE 2005), were checked and compared to official legislative lists for those states.

Scientific names were generally left as they were on the lists, despite many names no longer being valid due to changes in taxonomy. For instance, all Australian species of Bulbophyllum Thouars and all but one Australian Dendrobium Sw. species have been assigned to new genera (Jones 2006). However, in a few cases, species were listed under different names on different lists eg. the current name Corunatylis tecta (D.L. Jones) D.L. Jones \& M.A. Clem. is listed under the EPBC Act, while the former name Genoplesium tectum D.L. Jones is still listed under the Queensland Nature Conservation Act 1992. In these cases, the currently accepted scientific name has been used.

Definitions - Any examination of different systems for describing the conservation status of threatened species immediately runs into the issue of varying classification systems and definitions. The nine state/territory and national legislative systems collectively use eight terms to describe conservation status (Table 2). In this paper, the following definitions are used:

- Threatened includes 'critically endangered', 'endangered' and 'vulnerable' species (sensu IUCN 2001). Note that 'rare' is not generally included in the definition of 'threatened'.

- Conservation Concern includes all 'extinct', 'threatened', 'rare', 'insufficiently known' or 'data deficient' species (sensu Backhouse \& Cameron 2005).

- Listing is used to describe the formal process of adding a species to a threatened species list (usually called a Schedule) in biodiversity conservation legislation (Act).

\section{Results}

NATIONAL ASSESSMENT - A total of 424 orchid species are listed as extinct, threatened or rare in Australia (Appendix 1, summarised in Table 2). This total includes 195 species (about 12\% of the Australian orchid flora) listed as extinct or threatened nationally, plus an additional 238 species (about $14 \%$ of the
TABLE 2. Number of extinct, threatened and rare orchid species in Australia by jurisdiction.

\begin{tabular}{|l|r|r|r|r|r|r|r|r|r|}
\hline & NAT & \multicolumn{1}{|l|}{ NT } & \multicolumn{1}{|l|}{ QId } & NSW & ACT & Vic & \multicolumn{1}{|l|}{ Tas } & \multicolumn{1}{l|}{ SA } & WA \\
\hline EX & 7 & 0 & 3 & 0 & & & 2 & 0 & 0 \\
\hline EW & 0 & & & & & & & & \\
\hline CR & 23 & & & 0 & & & 2 & & \\
\hline EN & 91 & 2 & 19 & 33 & 3 & & 47 & 45 & \\
\hline VU & 74 & 6 & 25 & 21 & & & 3 & 31 & \\
\hline RA & & & 60 & & & & 15 & 28 & 36 \\
\hline TH & & & & & & 75 & & & \\
\hline CD & 0 & & & & & & & & \\
\hline Totals & $\mathbf{1 9 5}$ & $\mathbf{8}$ & $\mathbf{1 0 7}$ & $\mathbf{5 4}$ & $\mathbf{3}$ & $\mathbf{7 5}$ & $\mathbf{6 9}$ & $\mathbf{1 0 4}$ & $\mathbf{3 6}$ \\
\hline
\end{tabular}

Shaded boxes indicate where the conservation status category is not used in the national/state/territory legislation

\section{$\underline{\text { Abbreviations }}$}

Rows are conservation status categories: $\mathrm{EX}=$ extinct; $\mathrm{EW}=$ extinct in the Wild; $\mathrm{CR}=$ critically endangered; $\mathrm{EN}=$ endangered; $\mathrm{VU}=$ vulnerable $\mathrm{RA}=$ rare $\mathrm{TH}=$ threatened $\mathrm{CD}=$ conservation cependent

Columns are jurisdictions: $\mathrm{NAT}=$ National; $\mathrm{NT}=$ Northern Territory; Q1d = Queensland; NSW = New South Wales; ACT = Australian Capital Territory; Vic $=$ Victoria; Tas $=$ Tasmania; $\mathrm{SA}=$ South Australia; WA = Western Australia.

Australian orchid flora) listed as extinct, threatened or rare at the regional (ie. state or territory) level. State and territory threatened species lists include another 52 species that are listed as extinct or threatened within their jurisdiction (Appendix 2), that would also qualify as threatened nationally, but are not yet included on the national threatened species list. An additional 54 species are listed under the category of 'rare' within the relevant jurisdiction (Appendix 3), that would also have this status nationally, but are not on the national threatened species list. There are seven species of orchids included on the national EPBC Act threatened species lists that are not included in the relevant state/territory threatened species list (Appendix 4). An additional two threatened orchids on the national list, Dendrobium brachypus (End1.) H.G. Reichb. and Phreatia paleata H.G. Reichb., occur on Australia's island territories not under state/territory jurisdiction.

Regional assessments - For South Australia, the assessment by Bates (2006) indicated 146 orchids of 'Conservation Concern', compared with 104 listed under state legislation (Table 3). For Victoria, the two assessments indicated a total of 240 (Backhouse \& Cameron 2005) and 257 orchids (DSE 2005) of 
TABLE 3. Assessments of the numbers of orchids of 'conservation concern' in South Australia.

\begin{tabular}{l|c|c} 
Category & NPWA & Bates (2006) \\
\hline extinct & 0 & 14 \\
\hline endangered & 45 & 51 \\
\hline vulnerable & 31 & 20 \\
\hline threatened & 76 & 71 \\
\hline rare & 28 & 48 \\
\hline data deficient & 0 & 13 \\
\hline Total conservation concern & 104 & 146 \\
\hline
\end{tabular}

NPWA = National Parks \& Wildlife Act 1972, South Australia

'Conservation Concern', compared with just 75 orchids listed under state legislation (Table 4).

\section{Discussion}

The national EPBC Act includes 195 orchid species listed as extinct or threatened nationally (Table 2), which is about $12 \%$ of the Australian orchid flora. The state and territory regional threatened species lists include another 52 species that are listed as extinct or threatened within their jurisdiction, that would also qualify as threatened nationally, but are not yet included on the national threatened species list. If these species are added, the total national extinct/threatened orchid count is $15 \%$ of the nation's orchids. An additional 54 species are listed under the category of 'rare' within the relevant jurisdiction that would have this status at the national level. Therefore, there is a total of 301 species of orchids of conservation concern (= extinct, threatened or rare) at the national level, that are currently listed on national and regional biodiversity conservation legislation. This is $18 \%$ of the Australian orchid flora. Based solely on a comparison of the official national and state/territory legislative threatened species lists, it appears that the official national list underestimates the real number of threatened orchids by at least 50 species, and perhaps as many as 100 or more species.

The comparisons of the comprehensive reviews of the conservation status of the orchid flora of South Australia (Bates 2006) and Victoria (Backhouse \& Cameron 2005, DSE 2005) with listed threatened orchids in those states provides further evidence that official lists are a substantial underestimate of the
TABLE 4. Assessments of the numbers of orchids of 'conservation concern' in Victoria.

\begin{tabular}{|l|r|r|r|}
\hline \multicolumn{1}{|c|}{ Category } & FFGA & B\&C 2005 & DSE 2005 \\
\hline extinct & & 11 & 11 \\
\hline critically endangered & & 79 & 95 \\
\hline edangered & & 26 & 49 \\
\hline vlnerable & & 92 & $\mathbf{1 4 4}$ \\
\hline threatened & $\mathbf{7 5}$ & $\mathbf{1 9 7}$ & \\
\hline near threatened & & 8 & 43 \\
\hline data deficient & & 24 & 59 \\
\hline insufficiently known & & & $\mathbf{2 5 7}$ \\
\hline rare & & & \\
\hline Total conservation concern & $\mathbf{7 5}$ & $\mathbf{2 4 0}$ & \\
\hline
\end{tabular}

Shaded boxes indicate where the conservation status category is not used in the assessment system

FFGA = Flora and Fauna Guarantee Act 1988, Victoria. B\&C $2005=$ Backhouse \& Cameron 2005

actual number of threatened orchids. In South Australia, the number listed under the NPW Act may be an underestimate of the actual number of extinct, threatened or rare orchids by at least 42 species, based on Bates (2006) (Table 3). There is good evidence to suggest that at least 14 (and perhaps as many as 20) orchid species have become extinct in that state (Bates 2006), yet no orchid is currently listed as extinct under the NPW Act. In Victoria, there appears to be a much larger discrepancy between the official and actual number of threatened orchids. There are at least 150 extinct or threatened orchid species (DSE 2005), and perhaps over 200 (Backhouse \& Cameron 2005), compared with only 75 species listed as threatened under the Victorian Flora and Fauna Guarantee Act 1988.

These figures also do not take account of recent taxonomic advances. For example, 90 new species of orchids for Australia were described in late 2006 (Jones 2006b, 2006c, Jones \& Clements 2006, Jones \& Rouse 2006, Jones et. al 2006), of which at least one was considered extinct and 53 considered threatened. Most of these species have yet to be included on any threatened species list.

This review and assessments strongly suggests that official lists of threatened orchids at both the national and state/territory level are a substantial underesti- 
mate of the actual numbers of threatened orchids in Australia. There are several possible reasons for this large discrepancy.

LISTING PROCESS - The process to officially list a species as threatened can take a considerable period of time. Several jurisdictions have a similar listing process that includes the following steps:

- a species is nominated for listing;

- the nomination is assessed by a scientific reference committee;

- the committee makes a recommendation to list (or not list) to the relevant government minister;

- the recommendation is advertised for public comment;

- the committee makes a final recommendation to list (or not list);

- the government makes the listing.

In Victoria, under the FFG Act, the process takes a minimum of nine months in straightforward cases, and can take well over a year in complicated or contentious cases. Therefore, the listing process can lag well behind an initial assessment of threat. It is likely to be some years yet before the national threatened species list includes most or all orchids currently considered threatened.

TAXONOMY - There are many known but undescribed orchid species considered threatened (eg. Backhouse \& Cameron 2005, DSE 2005, Bates 2006) that are not yet listed. If a species is not formally named, there is an understandable reluctance to list an essentially unknown entity. However, several jurisdictions have provision for listing known but undescribed species, and some undescribed orchids are listed at the state and national level (see Appendix 1). The recent description of over 50 new species considered threatened nationally (Jones 2006b, 2006c, Jones \& Clements 2006, Jones \& Rouse 2006, Jones et. al 2006) will greatly assist the prospects for these species being eventually listed.

DiFFERING THREAT ASSESSMENTS - Differing assessments of conservation status under different jurisdictions, and the use of different assessment systems, may also be hindering the listing of nationally threatened orchids. While there may be some commonality between terminology used in most lists (eg. extinct, endangered, vulnerable), definitions do vary. Several state/territory lists still use 'rare', which is not regarded as a category of threat, and at least 54 species are rare at the national level. At least some of these species listed may well qualify for listing as threatened under national legislation. For instance, an assessment of the 45 orchid species considered rare in Victoria (DSE 2005) against IUCN 2001 categories found that $32(71 \%)$ of these species were threatened, with 30 being assessed as vulnerable (Backhouse \& Cameron 2005). The Queensland Government is phasing out the term 'rare' from its legislative list and current rare species will be reassessed to determine if any are threatened, although this won't happen until 2010. Even some publications use inconsistent standards when describing conservation status. For instance, Riley and Banks (2002) often use 'rare' in combination with a threat category (eg. rare and endangered; rare and vulnerable) when describing conservation status. Jones (2006b) uses IUCN 2001 for some conservation status assessments of threatened orchids, and a system known as AROTs (Australian Rare or Threatened Species, sensu Briggs \& Leigh 1996) for other assessments, with several potentially threatened orchids being assessed as rare.

\section{Recommendations}

This review and assessment of national and state/territory lists of threatened orchids in Australia has highlighted several deficiencies in the multiplicity of systems adopted by the different jurisdictions. Following are five recommendations proposed to improve the system for listing threatened orchids in Australia:

1. Undertake a comprehensive national review of the conservation status of Australia's orchids.

A comprehensive national review and assessment of the conservation status of Australian orchids is highly desirable, as the most suitable and rapid way to bring national and regional threatened species lists up to date. This review should be undertaken using a single assessment system, preferably the IUCN Red List Categories and Criteria (IUCN 2001). This national review could easily be adapted for state/territory jurisdictions through the use of the IUCN regional assessment guidelines (IUCN 2003) in undertaking 
the conservation status assessments. The national conservation status assessment could be modelled in the form of similar assessments in the national 'Action Plan' series undertaken for Australia's vertebrate fauna (eg. Wager \& Jackson 1993, Bannister et al. 1996, Garnett \& Crowley 2000) and butterflies (Sands \& New 2003). This review can form the basis of a concerted approach to formally listing the large number of threatened orchids not currently on official legislative lists.

2. Adopt a common set of categories and criteria for describing the conservation status of Australian orchids at both the national and regional (state/territory) level.

Currently the state, territory and national governments use different systems for describing conservation status, which can make for vague, confusing or conflicting definitions, and comparisons between lists difficult. Even in some recent publications, conservation status assessments can be confusing. The IUCN Red List Categories and Criteria (IUCN 2001) are the current international standard, and have been adapted for use in the national EPBC Act. This is the most logical system to use for assessing conservation status, especially with the guidelines for application at the regional level (IUCN 2003). This would provide a common language at the regional and national level in communicating conservation status of threatened orchids.

\section{Streamline administrative processes to facilitate cross listings of threatened orchids.}

Threatened orchids listed under state/territory legislation currently have to go through a separate process for listing under national legislation. There are at least 50 orchid species listed under state/territory legislation that would qualify for listing under national legislation, and at least another 50 species listed as rare that would possibly qualify for national listing. At the current rate of listing, it will take several years for these species to be assessed and listed at the national level. It is highly desirable that, in situations where a threatened species is listed in a state or territory, and is endemic to that state/territory, there is a simple administrative process to quickly list these species under national legislation.
4. Streamline administrative processes to accommodate changes in taxonomy.

There have been many taxonomic changes affecting Australian orchids, especially changes to genus names, in recent years, and further changes are likely. At least 50 threatened orchid species are currently listed under an invalid scientific name, with some of these names having changed several years ago. Current systems for listing threatened species under biodiversity conservation legislation at both the state/territory and national level do not adequately deal with taxonomic changes. For threatened species that have had a name change since listing, this effectively requires a nomination to delist under the old name and then nomination for relisting under the new name. A process is clearly required to rapidly update the legislative threatened species lists to accommodate advances in science and taxonomy. A mechanism for linking listed species names with official taxonomic checklists maintained by state/territory and national herbaria would provide an efficient way for dealing with taxonomic changes.

\section{Prepare national and regional (state/territory) advisory lists of threatened orchids.}

The preparation of non-legislative 'advisory' lists of threatened orchids is a useful way of fairly quickly accommodating changes in taxonomy, information and conservation status. These are peer-reviewed, and can be updated much more rapidly than is the case with legislative lists. For instance, the Victorian threatened species advisory lists (DSE 2003, 2005) are revised every $2-3$ years. While these advisory lists have no formal legislative standing, they are very useful as guides to the categories and number of threatened species, and can be used to highlight those species requiring formal listing under legislation.

ACKnowledgements. My thanks to Mr Adrian Moorrees and Dr Michael Duncan (department of Sustainability and Environment, Victoria). Mr David Jones (Centre for Plant Biodiversity Research, Canberra) provided information on the number of undescribed orchid species in Australia.

\section{LITERATURE CITED}

Backhouse, G. and Cameron, D. 2005. Application of IUCN Red List categories in determining the conserva- 
tion status of the native orchids in Victoria, Australia. Selbyana 26(1,2) : 58-74.

Bannister, J.L., Kemper, C.M. and Warneke, R.M. 1996. The action plan for Australian cetaceans. Environment Australia, Canberra.

Bates, R. 2006 (editor). South Australian native orchids. Native Orchid Society of South Australia Inc. Electronic version.

Briggs, J.D and Leigh, J.H. 1996. Rare or threatened Australian Plants, revised edition. CSIRO and Australian Nature Conservation Agency, Canberra.

DSE 2003. Advisory list of threatened vertebrate fauna in Victoria - 2003. Department of Sustainability and Environment, Victoria.

DSE 2005. Advisory list of rare or threatened plants in Victoria - 2005. Department of Sustainability and Environment, Victoria.

Garnett, S. T. and Crowley, G.M. 2000. The action plan for Australian birds. Environment Australia, Canberra.

IUCN 2001. IUCN Red List Categories and Criteria: Version 3.1. IUCN Species Survival Commission. IUCN, Gland and Cambridge.

IUCN 2003. Guidleines of Application of IUCN Red List Criteria at Regional Levels. Version 3.0. IUCN Species
Survival Commission. IUCN, Gland and Cambridge. Jones, D.L. 2006a. Native orchids of Australia. Reed New Holland, Frenchs Forest.

Jones, D.L. 2006b. Miscellaneous new species of Australian Orchidaceae. Aust. Orchid Res. 5 : 45-111.

Jones, D.L. 2006c. Towards a revision of Bunochilus D.L.Jones \& M.A.Clem. Aust. Orchid Res. 5 : 112-142.

Jones, D.L. and Clements, M.A. 2006. Fourteen new taxa of Orchidaceae from northern and eastern Australia and two new combinations from New Guinea. Aust. Orchid Res. 5 : 2-33.

Jones, D.L. and Rouse, D.T. 2006. Fourteen new species of Prasophyllum from eastern Australia. Aust. Orchid Res. 5 : 143-168.

Jones, D.L., Clements, M.A. and Sharma, Ish. 2006. Towards a revision of the Thelychiton speciosus group. Aust. Orchid Res. 5 : 34-44.

Riley, J. and Banks, D.P. 2002. Orchids of Australia. University of New South Wales Press, Sydney.

Sands, D.P.A. and New, T.R. 2002. The action plan for Australian butterflies. Environment Australia, Canberra.

Wager, R. and Jackson, P. 1993. The action plan for Australian freshwater fishes. Environment Australia, Canberra.

Gary Backhouse is a senior policy officer with the Department of Sustainability and Environment in Victoria, Australia, where he works on threatened species recovery programs. He has co-authored two books on orchids of Victoria, and has published numerous articles in the scientific and popular literature on threatened species and orchids. He is a keen traveller and photographer, and has a library of over 3000 species of orchids photographed in the wild from Australia, Africa, South-East Asia, New Guinea, New Zealand and the Americas. 
APPENDIX 1. Australian orchids listed as extinct, threatened or rare under national and state/territory biodiversity conservation legislation.

\begin{tabular}{|c|c|c|c|c|c|c|c|c|c|c|}
\hline $\mathbf{N}$ & Species & NAT & NT & QId & NSW & ACT & Vic & Tas & SA & WA \\
\hline 1 & Acianthus amplexicaulis & & & RA & & & & & & \\
\hline 2 & Acianthus collinus & & & & & & $\mathrm{TH}$ & & & \\
\hline 3 & Acianthus ledwardii & EX & & EX & & & & & & \\
\hline 4 & Acianthus sublestis & & & RA & & & & & & \\
\hline 5 & Acriopsis javanica & & & VU & & & & & & \\
\hline 6 & Aphyllorchis anomala & & & RA & & & & & & \\
\hline 7 & Aphyllorchis queenslandica & & & RA & & & & & & \\
\hline 8 & Bulbophyllum argyropus & & & RA & & & & & & \\
\hline 9 & Bulbophyllum blumei & & & EN & & & & & & \\
\hline 10 & Bulbophyllum boonjee & & & RA & & & & & & \\
\hline 11 & Bulbophyllum globuliforme & VU & & RA & VU & & & & & \\
\hline 12 & Bulbophyllum gracillimum & $\mathrm{VU}$ & & $\mathrm{VU}$ & & & & & & \\
\hline 13 & Bulbophyllum grandimesense & & & RA & & & & & & \\
\hline 14 & Bulbophyllum longiflorum & $\mathrm{VU}$ & & $\mathrm{VU}$ & & & & & & \\
\hline 15 & Bulbophyllum weinthalii & & & $\mathrm{VU}$ & & & & & & \\
\hline 16 & Bulbophyllum windsorense & & & RA & & & & & & \\
\hline 17 & Bulbophyllum wolfei & & & RA & & & & & & \\
\hline 18 & Cadetia collinsii & & & RA & & & & & & \\
\hline 19 & Cadetia wariana & & & RA & & & & & & \\
\hline 20 & Caladenia actensis & $\mathrm{CR}$ & & & & EN & & & & \\
\hline 21 & Caladenia amoena & EN & & & & & TH & & & \\
\hline 22 & Caladenia anthracina & $\mathrm{CR}$ & & & & & & $\mathrm{CR}$ & & \\
\hline 23 & Caladenia arenaria & EN & & & EN & & & & & \\
\hline 24 & Caladenia argocalla & EN & & & & & & & EN & \\
\hline 25 & Caladenia atroclavia & EN & & EN & & & & & & \\
\hline 26 & Caladenia audasii & EN & & & & & $\mathrm{TH}$ & & EN & \\
\hline 27 & Caladenia aurantiaca & & & & & & & EN & & \\
\hline 28 & Caladenia australis & & & & & & & EN & & \\
\hline 29 & Caladenia barbarella & $\mathrm{VU}$ & & & & & & & & RA \\
\hline 30 & Caladenia behrii & EN & & & & & & & EN & \\
\hline 31 & Caladenia bicalliata & & & & & & & & RA & \\
\hline 32 & Caladenia brachyscapa & EX & & & & & TH & EN & & \\
\hline 33 & Caladenia brumalis & VU & & & & & & & VU & \\
\hline 34 & Caladenia bryceana subsp. bryceana & EN & & & & & & & & RA \\
\hline 35 & Caladenia bryceana subsp. cracens & $\mathrm{VU}$ & & & & & & & & RA \\
\hline 36 & Caladenia busselliana & EN & & & & & & & & RA \\
\hline 37 & Caladenia caesarea subsp. maritima & EN & & & & & & & & RA \\
\hline 38 & Caladenia calcicola & $\mathrm{VU}$ & & & & & TH & & $\mathrm{VU}$ & \\
\hline 39 & Caladenia campbellii & $\mathrm{CR}$ & & & & & & $\mathrm{CR}$ & & \\
\hline 40 & Caladenia cardiochila & & & & & & & EX & & \\
\hline 41 & Caladenia caudata & VU & & & & & & RA & & \\
\hline 42 & Caladenia christineae & $\mathrm{VU}$ & & & & & & & & RA \\
\hline 43 & Caladenia clavigera & & & & & & & & EN & \\
\hline 44 & Caladenia cleistogama & & & & & & & & $\mathrm{VU}$ & \\
\hline 45 & Caladenia colorata & EN & & & & & & & EN & \\
\hline 46 & Caladenia concolor & VU & & & EN & & $\mathrm{TH}$ & & & \\
\hline 47 & Caladenia conferta & & & & & & & & EN & \\
\hline 48 & Caladenia congesta & & & & & & & EN & RA & \\
\hline 49 & Caladenia cruciformis & & & & & & $\mathrm{TH}$ & & & \\
\hline 50 & Caladenia cucullata & & & & & & & & RA & \\
\hline 51 & Caladenia dienema & $\mathrm{CR}$ & & & & & & VU & & WA \\
\hline
\end{tabular}




\begin{tabular}{|c|c|c|c|c|c|c|c|c|c|c|}
\hline $\mathbf{N}$ & Species & NAT & NT & Qld & NSW & ACT & Vic & Tas & SA & WA \\
\hline$\overline{52}$ & Caladenia dorrienii & $\overline{\mathrm{EN}}$ & & & & & & & & RA \\
\hline 53 & Caladenia drakeoides & EN & & & & & & & & RA \\
\hline 54 & Caladenia elegans & EN & & & & & & & & RA \\
\hline 55 & Caladenia excelsa & EN & & & & & & & & RA \\
\hline 56 & Caladenia filamentosa & & & & & & & RA & & \\
\hline 57 & Caladenia formosa & VU & & & & & TH & & $\mathrm{VU}$ & \\
\hline 58 & Caladenia fragrantissima & & & & & & $\mathrm{TH}$ & & RA & \\
\hline 59 & Caladenia fulva & EN & & & & & $\mathrm{TH}$ & & & \\
\hline 60 & Caladenia gladiolata & EN & & & & & & & EN & \\
\hline 61 & Caladenia gracilis & & & & & & & & EN & \\
\hline 62 & Caladenia graniticola & & & & & & & & & RA \\
\hline 63 & Caladenia harringtoniae & VU & & & & & & & & RA \\
\hline 64 & Caladenia hastata & EN & & & & & TH & & & \\
\hline 65 & Caladenia hoffmanii & EN & & & & & & & & RA \\
\hline 66 & Caladenia huegelii & EN & & & & & & & & RA \\
\hline 67 & Caladenia insularis & $\mathrm{VU}$ & & & & & TH & & & \\
\hline 68 & Caladenia lindleyana & CR & & & & & & EN & & \\
\hline 69 & Caladenia lowanensis & EN & & & & & TH & & & \\
\hline 70 & Caladenia macroclavia & EN & & & & & & & EN & \\
\hline 71 & Caladenia magnifica & & & & & & TH & & & \\
\hline 72 & Caladenia melanema & & & & & & & & & RA \\
\hline 73 & Caladenia minor & & & & & & & & RA & \\
\hline 74 & Caladenia necrophylla & & & & & & & & RA & \\
\hline 75 & Caladenia ornata & VU & & & & & & & & \\
\hline 76 & Caladenia orientalis & EN & & & & & TH & & & \\
\hline 77 & Caladenia ovata & $\mathrm{VU}$ & & & & & & & VU & \\
\hline 78 & Caladenia pallida & $\mathrm{CR}$ & & & & & & EN & & \\
\hline 79 & Caladenia parva & & & & & & & & EN & \\
\hline 80 & Caladenia patersonii & & & & & & & VU & & \\
\hline 81 & Caladenia pilotensis & & & & & & $\mathrm{TH}$ & & & \\
\hline 82 & Caladenia porphyrea & & & & EN & & & & & \\
\hline 83 & Caladenia procera & & & & & & & & & RA \\
\hline 84 & Caladenia prolata & & & & & & & EN & & \\
\hline 85 & Caladenia pumila & EX & & & & & TH & & & \\
\hline 86 & Caladenia pusilla & & & & & & & RA & & \\
\hline 87 & Caladenia richardsiorum & EN & & & & & & & EN & \\
\hline 88 & Caladenia rigida & EN & & & & & & & EN & \\
\hline 89 & Caladenia robinsonii & EN & & & & & TH & & & \\
\hline 90 & Caladenia rosella & EN & & & & & $\mathrm{TH}$ & & & \\
\hline 91 & Caladenia saggicola & $\mathrm{CR}$ & & & & & & EN & & \\
\hline 92 & Caladenia subulata & EN & & & & & $\mathrm{TH}$ & & & \\
\hline 93 & Caladenia sylvicola & $\mathrm{CR}$ & & & & & & EN & & \\
\hline 94 & Caladenia tensa & EN & & & & & & & & \\
\hline 95 & Caladenia tessellate & $\mathrm{VU}$ & & & EN & & & & & \\
\hline 96 & Caladenia thysanochila & EN & & & & & $\mathrm{TH}$ & & & \\
\hline 97 & Caladenia tonellii & $\mathrm{CR}$ & & & & & & EN & & \\
\hline 98 & Caladenia toxochila & & & & & & TH & & & \\
\hline 99 & Caladenia valida & & & & & & TH & & RA & \\
\hline 100 & Caladenia venusta & & & & & & & & $\mathrm{VU}$ & \\
\hline 101 & Caladenia versicolor & VU & & & & & TH & & VU & \\
\hline 102 & Caladenia viridescens & EN & & & & & & & & RA \\
\hline 103 & Caladenia vulgaris & & & & & & & & RA & \\
\hline 104 & Caladenia wanosa & $\mathrm{VU}$ & & & & & & & & RA \\
\hline 105 & Caladenia williamsiae & & & & & & & & & RA \\
\hline
\end{tabular}




\begin{tabular}{|c|c|c|c|c|c|c|c|c|c|c|}
\hline $\mathbf{N}$ & Species & NAT & NT & Qld & NSW & ACT & Vic & Tas & SA & WA \\
\hline 106 & Caladenia winfieldii & EN & & & & & & & & RA \\
\hline 107 & Caladenia woolcockiorum & VU & & & & & & & $\mathrm{VU}$ & \\
\hline 108 & Caladenia xanthochila & EN & & & & & $\mathrm{TH}$ & & EN & \\
\hline 109 & Caladenia xantholeuca & EN & & & & & & & EN & \\
\hline 110 & Caladenia species 'Bordertown' & & & & & & & & EN & \\
\hline 111 & Caladenia colorata & & & & & & TH & & & \\
\hline 112 & Caladenia species 'Finniss' & & & & & & & & EN & \\
\hline 113 & Caladenia species aff. fragrantissima & & & & & & $\mathrm{TH}$ & & & \\
\hline 114 & Caladenia species 'Jarrah forest' & VU & & & & & & & & \\
\hline 115 & Caladenia species 'Koolunga' & & & & & & & & EN & \\
\hline 116 & Caladenia species aff. rosella & & & & & & $\mathrm{TH}$ & & & \\
\hline 117 & Caladenia species aff. venusta & $\mathrm{CR}$ & & & & & $\mathrm{TH}$ & & & \\
\hline 118 & Caleana major & & & & & & & & VU & \\
\hline 119 & Calochilus caeruleus & & VU & & & & & & & \\
\hline 120 & Calochilus campestris & & & & & & & & RA & \\
\hline 121 & Calochilus cupreus & & & & & & & & EN & \\
\hline 122 & Calochilus paludosus & & & & & & & & VU & \\
\hline 123 & Calochilus psednus & EN & & EN & & & & & & \\
\hline 124 & Calochilus richiae & EN & & & & & $\mathrm{TH}$ & & & \\
\hline 125 & Chiloglottis anaticeps & & & & EN & & & & & \\
\hline 126 & Chiloglottis cornuta & & & & & & & & EN & \\
\hline 127 & Chiloglottis longiclavata & & & RA & & & & & & \\
\hline 128 & Chiloglottis platyptera & & & & $\mathrm{VU}$ & & & & & \\
\hline 129 & Chiloglottis seminuda & & & & & & $\mathrm{TH}$ & & & \\
\hline 130 & Chiloglottis sphyrnoides & & & $\mathrm{VU}$ & & & & & & \\
\hline 131 & Chiloglottis trapeziformis & & & & & & & & EN & \\
\hline 132 & Corunastylis brachystachya & EN & & & & & & EN & & \\
\hline 133 & Corunastylis ectopa & $\mathrm{CR}$ & & & & EN & & & & \\
\hline 134 & Corunastylis firthii & $\mathrm{CR}$ & & & & & & EN & & \\
\hline 135 & Corunastylis morrisii & & & & & & & EN & EN & \\
\hline 136 & Corunastylis nuda & & & & & & & RA & & \\
\hline 137 & Corunastylis nudiscapa & & & & & & & EX & & \\
\hline 138 & Corybas abellianus & & & RA & & & & & & \\
\hline 139 & Corybas dentatus & $\mathrm{VU}$ & & & & & & & EN & \\
\hline 140 & Corybas despectans & & & & & & $\mathrm{TH}$ & & & \\
\hline 141 & Corybas fordhamii & & & & & & & EN & EN & \\
\hline 142 & Corybas montanus & VU & & VU & & & & & & \\
\hline 143 & Corybas neocaledonicus & & & RA & & & & & & \\
\hline 144 & Corybas unguiculatus & & & & & & & & RA & \\
\hline 145 & Corybas species aff. diemenicus (coastal) & & & & & & TH & & & \\
\hline 146 & Corybas species 'Finniss' & EN & & & & & & & EN & \\
\hline 147 & Cryptostylis erecta & & & & & & TH & & & \\
\hline 148 & Cryptostylis hunteriana & VU & & & $\mathrm{VU}$ & & TH & & & \\
\hline 149 & Cryptostylis leptochila & & & & & & & EN & & \\
\hline 150 & Cryptostylis subulata & & & & & & & & VU & \\
\hline 151 & Cyrtostylis robusta & & & & & & & RA & & \\
\hline 152 & Dendrobium antennatum & EN & & EN & & & & & & \\
\hline 153 & Dendrobium bigibbum & VU & & VU & & & & & & \\
\hline 154 & Dendrobium brachypus & EN & & & & & & & & \\
\hline 155 & Dendrobium callitrophilum & VU & & $\mathrm{VU}$ & & & & & & \\
\hline 156 & Dendrobium carronii & VU & & VU & & & & & & \\
\hline 157 & Dendrobium fellowsii & & & RA & & & & & & \\
\hline 158 & Dendrobium johannis & $\mathrm{VU}$ & & VU & & & & & & \\
\hline 159 & Dendrobium lithocola & EN & & EN & & & & & & \\
\hline
\end{tabular}




\begin{tabular}{|c|c|c|c|c|c|c|c|c|c|c|}
\hline $\mathbf{N}$ & Species & NAT & NT & Qld & NSW & ACT & Vic & Tas & SA & WA \\
\hline 160 & Dendrobium malbrownii & & & RA & & & & & & \\
\hline 161 & Dendrobium melaleucaphilum & & & & EN & & & & & \\
\hline 162 & Dendrobium mirbelianum & EN & & EN & & & & & & \\
\hline 163 & Dendrobium nindii & EN & & EN & & & & & & \\
\hline 164 & Dendrobium phalaenopsis & $\mathrm{VU}$ & & VU & & & & & & \\
\hline 165 & Dendrobium schneiderae var. schneiderae & & & RA & & & & & & \\
\hline 166 & Dendrobium speciosum & & & & & & $\mathrm{TH}$ & & & \\
\hline 167 & Dendrobium superbiens & VU & & VU & & & & & & \\
\hline 168 & Didymoplexis pallens & & & RA & & & & & & \\
\hline 169 & Diplocaulobium masonii & EX & & EX & & & & & & \\
\hline 170 & Dipodium campanulatum & & & & & & & & $\mathrm{VU}$ & \\
\hline 171 & Dipodium hamiltonianum & & & & & & $\mathrm{TH}$ & & & \\
\hline 172 & Dipodium pardalinum & & & & & & & & VU & \\
\hline 173 & Dipodium pictum & EN & & EN & & & & & & \\
\hline 174 & Dipodium pulchellum & & & RA & & & & & & \\
\hline 175 & Diuris aequalis & VU & & & EN & & & & & \\
\hline 176 & Diuris arenaria & & & & EN & & & & & \\
\hline 177 & Diuris behrii & & & & & & & & RA & \\
\hline 178 & Diuris bracteata & EX & & & EN & & & & & \\
\hline 179 & Diuris brevifolia & & & & & & & & RA & \\
\hline 180 & Diuris chryseopsis & & & & & & & & EN & \\
\hline 181 & Diuris dendrobioides & & & & & & $\mathrm{TH}$ & & & \\
\hline 182 & Diuris disposita & & & & EN & & & & & \\
\hline 183 & Diuris drummondii & VU & & & & & & & & RA \\
\hline 184 & Diuris flavescens & & & & EN & & & & & \\
\hline 185 & Diuris fragrantissima & EN & & & & & $\mathrm{TH}$ & & & \\
\hline 186 & Diuris lanceolata & EN & & & & & & EN & & \\
\hline 187 & Diuris micrantha & VU & & & & & & & & RA \\
\hline 188 & Diuris ochroma & VU & & & EN & & $\mathrm{TH}$ & & & \\
\hline 189 & Diuris oporina & & & RA & & & & & & \\
\hline 190 & Diuris palustris & & & & & & $\mathrm{TH}$ & EN & & \\
\hline 191 & Diuris parvipetala & & & RA & & & & & & \\
\hline 192 & Diuris pedunculata & EN & & & EN & & & & & \\
\hline 193 & Diuris praecox & VU & & & VU & & & & & \\
\hline 194 & Diuris punctata var. punctata & & & & & & $\mathrm{TH}$ & & EN & \\
\hline 195 & Diuris purdiei & EN & & & & & & & & RA \\
\hline 196 & Diuris sheaffiana & $\mathrm{VU}$ & & & & & & & & \\
\hline 197 & Diuris sulphurea & & & & & & & & RA & \\
\hline 198 & Diuris tricolor & & & & VU & & $\mathrm{TH}$ & & & \\
\hline 199 & Diuris venosa & VU & & & $\mathrm{VU}$ & & & & & \\
\hline 200 & Diuris species aff. lanceolata & EN & & & & & TH & & & \\
\hline 201 & Diuris species aff. chrysantha 'Byron & & & & EN & & & & & \\
\hline 202 & Bay’' & & & & EN & & & & & \\
\hline 203 & Diuris species 'Oaklands' & & & RA & & & & & & \\
\hline 204 & Dockrillia wassellii & VU & & & & & & & & \\
\hline 205 & Drakaea concolor & EN & & & & & & & & RA \\
\hline 206 & Drakaea confluens & EN & & & & & & & & RA \\
\hline 207 & Drakaea elastica & EN & & & & & & & & RA \\
\hline 208 & Drakaea isolata & VU & & & & & & & & RA \\
\hline 209 & Drakaea micrantha & EN & & & & & & & & RA \\
\hline 210 & Epiblema grandiflorum var. cyaneum & & & RA & & & & & & RA \\
\hline 211 & Eria dischorensis & & & RA & & & & & & \\
\hline 212 & Eria irukandjiana & & & RA & & & & & & \\
\hline 213 & Eulophia bicallosa & & & RA & & & & & & \\
\hline
\end{tabular}




\begin{tabular}{|c|c|c|c|c|c|c|c|c|c|c|}
\hline $\mathbf{N}$ & Species & NAT & NT & Qld & NSW & ACT & Vic & Tas & SA & WA \\
\hline 214 & Eulophia zollingeri & & & RA & & & & & & \\
\hline 215 & Gastrodia crebrifolia & & & RA & & & & & & \\
\hline 216 & Gastrodia queenslandica & & & RA & & & & & & \\
\hline 217 & Gastrodia urceolata & & & & & & & & RA & \\
\hline 218 & Gastrodia sesamoides & & & & & & & & $\mathrm{VU}$ & \\
\hline 219 & Gastrodia vescula & & & RA & & & & & & \\
\hline 220 & Genoplesium alticolum & & & & $\mathrm{VU}$ & & & & & \\
\hline 221 & Genoplesium baueri & & & & & & & & EN & \\
\hline 222 & Genoplesium ciliatum & & & & & & & & $\mathrm{VU}$ & \\
\hline 223 & Genoplesium despectans & & & & EN & & & & & \\
\hline 224 & Genoplesium insignis & & & RA & & & & & & \\
\hline 225 & Genoplesium pedersonii & EN & & & EN & & & & & \\
\hline 226 & Genoplesium plumosum & EN & & & EN & & & & & \\
\hline 227 & Genoplesium rhyoliticum & & & RA & & & & & & \\
\hline 228 & Genoplesium sigmoideum & & & & EN & & & & & \\
\hline 229 & Genoplesium superbum & VU & & & VU & & & & & \\
\hline 230 & Genoplesium vernale & EN & & EN & & & & & & \\
\hline 231 & Genoplesium tectum & & & RA & & & & & & \\
\hline 232 & Genoplesium validum & & & & EN & & & & & \\
\hline 233 & Geodorum densiflorum & VU & & VU & & & & & & \\
\hline 234 & Grastidium tozerense & & & RA & & & & & & \\
\hline 235 & Habenaria divaricata & & & EN & & & & & & \\
\hline 236 & Habenaria harroldii & & & RA & & & & & & \\
\hline 237 & Habenaria hymenophylla & EN & & EN & & & & & & \\
\hline 238 & Habenaria macraithii & & EN & & & & & & & \\
\hline 239 & Habenaria rumphii & & & RA & & & & & & \\
\hline 240 & Habenaria xanthantha & & & & & & & RA & & \\
\hline 241 & Hydrorchis orbicularis & & & RA & & & & & & \\
\hline 242 & Liparis condylobulbon & & & RA & & & & & & \\
\hline 243 & Liparis simmondsii & & VU & & & & & & & \\
\hline 244 & Luisia teretifolia & & $\mathrm{VU}$ & & & & & & & \\
\hline 245 & Malaxis latifolia & & VU & & & & & & & \\
\hline 246 & Malaxis marsupichila & & & & & & & RA & RA & \\
\hline 247 & Microtidium atratum & EN & & & EN & & & & & \\
\hline 248 & Microtis angusii & & & & & & & & & \\
\hline 249 & Microtis globula & & & & & & & & RA & RA \\
\hline 250 & Microtis orbicularis & & & & & & & & RA & \\
\hline 251 & Microtis rara & & & RA & & & & & & \\
\hline 252 & Nervilia crociformis & & EN & & & & & & & \\
\hline 253 & Nervilia plicata & EX & & EX & & & & & & \\
\hline 254 & Oberonia attenuata & & & RA & & & & & & \\
\hline 255 & Oberonia carnosa & & & & EN & & & & & \\
\hline 256 & Oberonia complanata & & & & VU & & & & & \\
\hline 257 & Oberonia titania & & & RA & & & & & & \\
\hline 258 & Pachystoma pubescens & & & RA & & & & & & \\
\hline 259 & Papillilabium beckleri & & & & & & $\mathrm{TH}$ & & EN & \\
\hline 260 & Paracaleana sp. aff. nigrita & EN & & & & & & & & \\
\hline 261 & Paracaleana dixonii & & & & & & & & $\mathrm{VU}$ & RA \\
\hline 262 & Paracaleana minor & & & RA & $\mathrm{VU}$ & & & & & \\
\hline 263 & Peristeranthus hillii & & & RA & & & & & & \\
\hline 264 & Peristylus banfieldii & EN & & EN & EN & & & & & \\
\hline 265 & Phaius australis & EN & & EN & & & & & & \\
\hline 266 & Phaius bernaysii & VU & & VU & & & & & & \\
\hline 267 & Phaius pictus & EN & & EN & EN & & & & & \\
\hline
\end{tabular}




\begin{tabular}{|c|c|c|c|c|c|c|c|c|c|c|}
\hline $\mathbf{N}$ & Species & NAT & NT & Qld & NSW & ACT & Vic & Tas & SA & WA \\
\hline 268 & Phaius tancarvilleae & EN & & EN & & & & & & \\
\hline 269 & Phalaenopsis rosenstromii & EN & & & & & & & & \\
\hline 270 & Phreatia paleata & VU & & VU & & & & & & \\
\hline 271 & Pomatocalpa marsupiale & EN & & & EN & & & & & \\
\hline 272 & Prasophyllum affine & EN & & & & & & EN & & \\
\hline 273 & Prasophyllum amoenum & EN & & & & & & EN & & \\
\hline 274 & Prasophyllum apoxychilum & & & & & & & & RA & \\
\hline 275 & Prasophyllum australe & & & & EN & & & & & \\
\hline 276 & Prasophyllum bagoensis & & & & & & & & VU & \\
\hline 277 & Prasophyllum calcicola & & & RA & & & & & & \\
\hline 278 & Prasophyllum campestre & CR & & & & & & EN & & \\
\hline 279 & Prasophyllum castaneum & EN & & & & & TH & & & \\
\hline 280 & Prasophyllum chasmogamum & VU & & & & & & & & \\
\hline 281 & Prasophyllum colemaniae & & & & & & & & RA & \\
\hline 282 & Prasophyllum constrictum & EN & & & & & TH & & & \\
\hline 283 & Prasophyllum diversiflorum & & & RA & & & & & & \\
\hline 284 & Prasophyllum exilis & CR & & & & & & EN & & \\
\hline 285 & Prasophyllum favonium & & & & & & & & RA & \\
\hline 286 & Prasophyllum fecundum & & & & & & TH & & & \\
\hline 287 & Prasophyllum fitzgeraldii & & & & & & TH & & & \\
\hline 288 & Prasophyllum fosteri & EN & & & & & TH & & EN & \\
\hline 289 & Prasophyllum frenchii & VU & & & VU & & & & & \\
\hline 290 & Prasophyllum fuscum & & & & & & & & RA & \\
\hline 291 & Prasophyllum goldsackii & & & & & & & EN & & \\
\hline 292 & Prasophyllum incorrectum & & & RA & & & & & & \\
\hline 293 & Prasophyllum incompositum & & & & & & TH & & & \\
\hline 294 & Prasophyllum litorale & CR & & & & & & EN & & \\
\hline 295 & Prasophyllum milfordense & & & & & & & EN & & \\
\hline 296 & Prasophyllum montanum & VU & & & & & TH & & & \\
\hline 297 & Prasophyllum morganii & & & & & & TH & & & \\
\hline 298 & Prasophyllum niphopedium & & & & & & & & RA & \\
\hline 299 & Prasophyllum occultans & CR & & & & & & EN & & \\
\hline 300 & Prasophyllum olidum & VU & & & & & & & VU & \\
\hline 301 & Prasophyllum pallidum & CR & & & & & & EN & & \\
\hline 302 & Prasophyllum perangustum & EN & & & EN & & & & & \\
\hline 303 & Prasophyllum petilum & & & & & & & & VU & \\
\hline 304 & Prasophyllum pruinosum & $\mathrm{CR}$ & & & & EN & & EN & & \\
\hline 305 & Prasophyllum pulchellum & & & & & & & EN & & \\
\hline 306 & Prasophyllum pyriforme & & & & VU & & & & & \\
\hline 307 & Prasophyllum retroflexum & CR & & & & & & EN & & \\
\hline 308 & Prasophyllum robustum & EN & & & & & & VU & & \\
\hline 309 & Prasophyllum secutum & VU & & & & & & & EN & \\
\hline 310 & Prasophyllum spicatum & $\mathrm{CR}$ & & & & & & EN & & \\
\hline 311 & Prasophyllum stellatum & EN & & & & & $\mathrm{TH}$ & & & \\
\hline 312 & Prasophyllum suaveolens & EN & & & & & TH & & & \\
\hline 313 & Prasophyllum subbisectu & & & & & & TH & & & \\
\hline 314 & Prasophyllum suttonii & & & & & & & RA & & \\
\hline 315 & Prasophyllum tadgellianum & & & & & & & EN & & \\
\hline 316 & Prasophyllum taphanyx & EN & & & & & & EN & & \\
\hline 317 & Prasophyllum tunbridgense & EN & & & EN & & & & & \\
\hline 318 & Prasophyllum uroglossum & VU & & & & & & & VU & \\
\hline 319 & Prasophyllum validum & VU & & VU & & & & & & \\
\hline 320 & Prasophyllum wallum & & & & EN & & & & & \\
\hline 321 & Prasophyllum species 'Majors Creek' & & & & & & $\mathrm{TH}$ & & & \\
\hline
\end{tabular}


\begin{tabular}{c|l} 
N & Prasophyllum species 'Nagambie'
\end{tabular}

\begin{tabular}{|l|l|l|l|l|l|l|l|l} 
NAT & NT & Qld & NSW & ACT & Vic & Tas & SA & WA \\
\hline EN & & & & & TH & & & \\
\hline VU & & & & & & & VU & \\
\hline EN & & & & & & EN & & \\
\hline & & & & & TH & & & \\
\hline EN & & & & & TH & & & \\
\hline VU & & VU & & & & & & \\
\hline & & & & & & & EN & \\
\hline
\end{tabular}

\begin{tabular}{l|l}
322 & Pterostylis aenigma \\
\hline 323 & Pterostylis arenicola
\end{tabular}

324 Pterostylis atriola

325 Pterostylis baptistii

326 Pterostylis basaltica

327 Pterostylis bicornis

328 Pterostylis bryophila

329 Pterostylis chaetophora

330 Pterostylis cheraphila

331 Pterostylis chlorogramma

332 Pterostylis cobarensis

333 Pterostylis commutata

334 Pterostylis concinna

335 Pterostylis cucullata

336 Pterostylis curta

337 Pterostylis cycnocephala

338 Pterostylis despectans

339 Pterostylis elegans

340 Pterostylis falcata

341 Pterostylis foliata

342 Pterostylis furcata

343 Pterostylis gibbosa

344 Pterostylis grandiflora

345 Pterostylis longicurva

346 Pterostylis metcalfei

347 Pterostylis nigricans

348 Pterostylis pratensis

349 Pterostylis pulchella

350 Pterostylis rubenachii

351 Pterostylis sanguinea

352 Pterostylis saxicola

353 Pterostylis setifera

354 Pterostylis squamata

355 Pterostylis tasmanica

356 Pterostylis tenuissima

357 Pterostylis truncata

358 Pterostylis tunstallii

359 Pterostylis uliginosa

360 Pterostylis valida

361 Pterostylis wapstrarum

362 Pterostylis woollsii

363 Pterostylis xerophila

364 Pterostylis ziegeleri

365 Pterostylis species 'Gundiah'

366 Pterostylis species aff. boormanii

367 Pterostylis species 'Botany Bay'

368 Pterostylis species 'Broughton Gorge'

369 Pterostylis species 'Eyre Peninsula'

370 Pterostylis species 'Halbury'

371 Pterostylis species 'Hale'

372 Pterostylis species 'Mt Bryan'

373 Pterostylis species 'Mt Olinthus'

374 Pterostylis species 'Mt Victoria Uranium Mine'

\begin{tabular}{l|l}
\hline 375 & Pterostylis species 'Northampton'
\end{tabular}

\begin{tabular}{|c|l|l}
\hline & & \\
\hline VU & & \\
\hline VU & & \\
VU & & \\
\hline CR & & \\
\hline VU & & \\
& & \\
\hline EN & & \\
\hline & &
\end{tabular}

EN

年

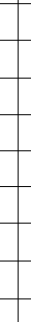

VU

\begin{tabular}{l|l}
\hline & \\
\hline &
\end{tabular}

EN

\begin{tabular}{|l|l|}
\hline & \\
\hline & \\
\hline
\end{tabular}

\begin{tabular}{|l}
\hline \\
\hline \\
\hline
\end{tabular}

\begin{tabular}{|l|l|l} 
& & $\mathrm{RA}$ \\
\hline & & \\
\hline VU & & RA \\
\hline VU & & \\
\hline
\end{tabular}

RA

\begin{tabular}{|l|l|}
\hline VU \\
\hline \\
\hline \\
\hline VU \\
\hline \\
\hline \\
\hline EN \\
\hline
\end{tabular}

\begin{tabular}{|l|l|}
\hline EN & \\
\hline & \\
\hline EN & \\
\hline
\end{tabular}

\begin{tabular}{|l}
\hline RA \\
\hline \\
\hline \\
\hline RA \\
\hline
\end{tabular}

EN

\begin{tabular}{|l|l|}
\hline & \\
\hline & \\
\hline & \\
\hline
\end{tabular}

\begin{tabular}{|l|l}
\hline TH & \\
\hline & \\
\hline & EN \\
\hline &
\end{tabular}




\begin{tabular}{|c|c|c|c|c|c|c|c|c|c|c|}
\hline $\mathbf{N}$ & Species & NAT & NT & Qld & NSW & ACT & Vic & Tas & SA & WA \\
\hline 376 & Pterostylis species 'Oratan Rock' & & & & & & & & $\mathrm{VU}$ & \\
\hline 377 & Pterostylis species aff. parviflora & & & & & & & & $\mathrm{VU}$ & \\
\hline 378 & Pterostylis species 'Sandy Creek' & & & & & & & & $\mathrm{VU}$ & \\
\hline 379 & Rhinerrhiza moorei & VU & & VU & & & & & & \\
\hline 380 & Rhizanthella slateri & & & RA & VU & & & & & \\
\hline 381 & Robiquetia wasselii & & & RA & & & & & & \\
\hline 382 & Sarcochilus dilatatus & & & & EN & & & & & \\
\hline 383 & Sarcochilus falcatus & & & & & & $\mathrm{TH}$ & & & \\
\hline 384 & Sarcochilus fitzgeraldii & $\mathrm{VU}$ & & EN & $\mathrm{VU}$ & & & & & \\
\hline 385 & Sarcochilus hartmannii & VU & & VU & VU & & & & & \\
\hline 386 & Sarcochilus hirticalcar & $\mathrm{VU}$ & & VU & & & & & & \\
\hline 387 & Sarcochilus roseus & $\mathrm{VU}$ & & $\mathrm{VU}$ & & & & & & \\
\hline 388 & Sarcochilus weinthalii & VU & & EN & VU & & & & & \\
\hline 389 & Schoenorchis sarcophylla & & & RA & & & & & & \\
\hline 390 & Spathoglottis paulinea & & & RA & & & & & & \\
\hline 391 & Spathoglottis plicata & VU & & $\mathrm{VU}$ & & & & & & \\
\hline 392 & Spiranthes australis & & & & & & & & RA & \\
\hline 393 & Taeniophyllum confertum & & & RA & & & & & & \\
\hline 394 & Taeniophyllum lobatum & & & RA & & & & & & \\
\hline 395 & Taeniophyllum muelleri & $\mathrm{VU}$ & & & & & & & & \\
\hline 396 & Thelasis carinata & & & RA & & & & & & \\
\hline 397 & Thelymitra antennifera & & & & & & & EN & & \\
\hline 398 & Thelymitra benthamiana & & & & & & & EN & & \\
\hline 399 & Thelymitra bracteata & & & & & & & EN & & \\
\hline 400 & Thelymitra carnea & & & & & & & & RA & \\
\hline 401 & Thelymitra circumsepta & & & & & & & & EN & \\
\hline 402 & Thelymitra deadmaniarum & EN & & & & & & & & RA \\
\hline 403 & Thelymitra epipactoides & EN & & & & & $\mathrm{TH}$ & & EN & \\
\hline 404 & Thelymitra flexиosa & & & & & & & & RA & \\
\hline 405 & Thelymitra gregaria & & & & & & TH & & & \\
\hline 406 & Thelymitra hiemalis & & & & & & $\mathrm{TH}$ & & & \\
\hline 407 & Thelymitra holmesii & & & & & & & RA & $\mathrm{VU}$ & \\
\hline 408 & Thelymitra jonesii & & & & & & & EN & & \\
\hline 409 & Thelymitra mackibbinii & VU & & & & & $\mathrm{TH}$ & & & \\
\hline 410 & Thelymitra malvina & & & & & & & EN & EN & \\
\hline 411 & Thelymitra matthewsii & VU & & & & & $\mathrm{TH}$ & & EN & \\
\hline 412 & Thelymitra merraniae & & & & & & $\mathrm{TH}$ & & & \\
\hline 413 & Thelymitra mucida & & & & & & & RA & RA & \\
\hline 414 & Thelymitra psammophila & VU & & & & & & & & RA \\
\hline 415 & Thelymitra stellata & EN & & & & & & & & RA \\
\hline 416 & Thelymitra venosa & & & & & & & & EN & \\
\hline 417 & Thrixspermum congestum & & VU & & & & & & & \\
\hline 418 & Thynninorchis huntiana & & & & & & & EN & & \\
\hline 419 & Thynninorchis nothofagicola & $\mathrm{CR}$ & & & & & & EN & & \\
\hline 420 & Trichoglottis australiensis & VU & & $\mathrm{VU}$ & & & & & & \\
\hline 421 & Vanda hindsii & VU & & $\mathrm{VU}$ & & & & & & \\
\hline 422 & Vrydagzynea paludosa & EN & & EN & & & & & & \\
\hline 423 & Zeuxine oblonga & & VU & & & & & & & \\
\hline \multirow[t]{2}{*}{424} & Zeuxine polygonoides & VU & & $\mathrm{VU}$ & & & & & & \\
\hline & Totals & 195 & 8 & 107 & 54 & 3 & 75 & 69 & 104 & \\
\hline
\end{tabular}

NAT $=$ National NT $=$ Northern Territory; Qld $=$ Queensland; NSW $=$ New South Wales ACT $=$ Australian Capital Territory; Vic $=$ Victoria Tas $=$ Tasmania; $\mathrm{SA}=$ South Australia; WA $=$ Western Australia . 
APPENDIX 2. Nationally threatened orchids listed at the state/territory level but not at the national level.

\begin{tabular}{|c|c|c|c|c|c|c|}
\hline $\mathbf{N}$ & Species & Qld & NSW & Vic & Tas & SA \\
\hline 1 & Acriopsis javanica & VU & & & & \\
\hline 2 & Caladenia conferta & & & & & EN \\
\hline 3 & Caladenia cruciformis & & & TH & & \\
\hline 4 & Caladenia fragrantissima & & & $\mathrm{TH}$ & & RA \\
\hline 5 & Caladenia magnifica & & & TH & & \\
\hline 6 & Caladenia patersonii & & & & VU & \\
\hline 7 & Caladenia pilotensis & & & TH & & \\
\hline 8 & Caladenia porphyrea & & $\mathrm{EN}$ & & & \\
\hline 9 & Caladenia valida & & & $\mathrm{TH}$ & & RA \\
\hline 10 & Caladenia species 'Bordertown' & & & & & $\mathrm{EN}$ \\
\hline 11 & Caladenia species 'Finniss' & & & & & $\mathrm{EN}$ \\
\hline 12 & Caladenia species aff. fragrantissima & & & TH & & \\
\hline 13 & Caladenia species 'Koolunga' & & & & & EN \\
\hline 14 & Caladenia species aff. rosella & & & $\mathrm{TH}$ & & \\
\hline 15 & Chiloglottis anaticeps & & $\mathrm{EN}$ & & & \\
\hline 16 & Chiloglottis platyptera & & VU & & & \\
\hline 17 & Genoplesium insignis & & $\mathrm{EN}$ & & & \\
\hline 18 & Genoplesium superbum & & EN & & & \\
\hline 19 & Diuris arenaria & & EN & & & \\
\hline 20 & Diuris species aff. chrysantha 'Byron Bay' & & EN & & & \\
\hline 21 & Diuris species 'Oaklands' & & EN & & & \\
\hline 22 & Gastrodia vescula & & & & & $\mathrm{VU}$ \\
\hline 23 & Genoplesium baueri & & VU & & & \\
\hline 24 & Habenaria harroldii & EN & & & & \\
\hline 25 & Peristeranthus hillii & RA & VU & & & \\
\hline 26 & Prasophyllum bagoensis & & EN & & & \\
\hline 27 & Prasophyllum fosteri & & & TH & & \\
\hline 28 & Prasophyllum incorrectum & & & & EN & \\
\hline 29 & Prasophyllum litorale & & & TH & & \\
\hline 30 & Prasophyllum niphopedium & & & TH & & \\
\hline 31 & Prasophyllum pruinosum & & & & & VU \\
\hline 32 & Prasophyllum retroflexum & & VU & & & \\
\hline 33 & Prasophyllum suttonii & & & TH & & \\
\hline 34 & Prasophyllum taphanyx & & & & EN & \\
\hline 35 & Prasophyllum species 'Majors Creek' & & EN & & & \\
\hline 36 & Prasophyllum species 'Nagambie' & & & TH & & \\
\hline 37 & Pterostylis bryophila & & & & & $\mathrm{EN}$ \\
\hline 38 & Pterostylis elegans & & VU & & & \\
\hline 39 & Pterostylis metcalfei & & EN & & & \\
\hline 40 & Pterostylis nigricans & RA & VU & & & \\
\hline 41 & Pterostylis species 'Broughton Gorge' & & & & & EN \\
\hline 42 & Pterostylis species 'Mt Bryan’ & & & & & EN \\
\hline 43 & Pterostylis species 'Mt Olinthus' & & & & & $\mathrm{EN}$ \\
\hline 44 & Pterostylis species 'Mt Victoria Uranium Mine' & & & & & VU \\
\hline 45 & Pterostylis species ‘Oratan Rock’ & & & & & VU \\
\hline 46 & Pterostylis species aff. parviflora & & & & & VU \\
\hline 47 & Pterostylis species 'Sandy Creek' & & & & & VU \\
\hline 48 & Rhizanthella slateri & RA & VU & & & \\
\hline 49 & Thelymitra gregaria & & & TH & & \\
\hline 50 & Thelymitra hiemalis & & & $\mathrm{TH}$ & & \\
\hline 51 & Thelymitra jonesii & & & & EN & \\
\hline 52 & Thelymitra merraniae & & & TH & & \\
\hline
\end{tabular}

Qld = Queensland; NSW = New South Wales; Vic = Victoria; Tas $=$ Tasmania; SA = South Australia. 
APPENDIX 3. Nationally rare orchids listed at the state/territory level but not at the national level.

\begin{tabular}{|c|c|c|c|c|}
\hline $\mathbf{N}$ & Species & Qld & $\mathbf{S A}$ & WA \\
\hline 1 & Acianthus amplexicaulis & RA & & \\
\hline 2 & Acianthus sublestis & RA & & \\
\hline 3 & Aphyllorchis anomala & RA & & \\
\hline 4 & Aphyllorchis queenslandica & RA & & \\
\hline 5 & Bulbophyllum blumei & EN & & \\
\hline 6 & Bulbophyllum boonjee & RA & & \\
\hline 7 & Bulbophyllum grandimesense & RA & & \\
\hline 8 & Bulbophyllum windsorense & RA & & \\
\hline 9 & Bulbophyllum wolfei & RA & & \\
\hline 10 & Cadetia collinsii & RA & & \\
\hline 11 & Cadetia wariana & RA & & \\
\hline 12 & Caladenia graniticola & & & RA \\
\hline 13 & Caladenia melanema & & & RA \\
\hline 14 & Caladenia minor & & RA & \\
\hline 15 & Caladenia necrophylla & & RA & \\
\hline 16 & Caladenia procera & & & RA \\
\hline 17 & Chiloglottis longiclavata & RA & & \\
\hline 18 & Corybas abellianus & RA & & \\
\hline 19 & Corybas neocaledonicus & RA & & \\
\hline 20 & Dendrobium fellowsii & RA & & \\
\hline 21 & Dendrobium malbrownii & RA & & \\
\hline 22 & Diuris oporina & RA & & \\
\hline 23 & Diuris parvipetala & RA & & \\
\hline 24 & Dockrillia wassellii & RA & & \\
\hline 25 & Eria dischorensis & RA & & \\
\hline 26 & Eria irukandjiana & RA & & \\
\hline 27 & Eulophia zollingeri & RA & & \\
\hline 28 & Gastrodia crebrifolia & RA & & \\
\hline 29 & Gastrodia queenslandica & RA & & \\
\hline 30 & Gastrodia urceolata & RA & & \\
\hline 31 & Genoplesium alticolum & RA & & \\
\hline 32 & Genoplesium pedersonii & RA & & \\
\hline 33 & Genoplesium sigmoideum & RA & & \\
\hline 34 & Genoplesium validum & RA & & \\
\hline 35 & Habenaria divaricata & RA & & \\
\hline 36 & Habenaria xanthantha & RA & & \\
\hline 37 & Liparis condylobulbon & RA & & \\
\hline 38 & Liparis simmondsii & RA & & \\
\hline 39 & Microtis globula & & & RA \\
\hline 40 & Nervilia crociformis & RA & & \\
\hline 41 & Oberonia carnosa & RA & & \\
\hline 42 & Peristylus banfieldii & RA & & \\
\hline 43 & Prasophyllum constrictum & & RA & \\
\hline 44 & Prasophyllum fecundum & & RA & \\
\hline 45 & Prasophyllum goldsackii & & RA & \\
\hline 46 & Prasophyllum incompositum & RA & & \\
\hline 47 & Prasophyllum occultans & & RA & \\
\hline 48 & Pterostylis species 'Gundiah' & RA & & \\
\hline 49 & Robiquetia wasselii & RA & & \\
\hline 50 & Schoenorchis sarcophylla & RA & & \\
\hline 51 & Spathoglottis paulinea & RA & & \\
\hline 52 & Taeniophyllum confertum & RA & & \\
\hline 53 & Taeniophyllum lobatum & RA & & \\
\hline 54 & Thelasis carinata & RA & & \\
\hline
\end{tabular}

Qld = Queensland; SA = South Australia; WA = Western Australia 